\title{
INTRUSIVE ROCKS OF THE MIDSOMMERS $\varnothing$ AREA, SOUTHERN PEARY LAND AND THEIR STRATIGRAPHICAL POSITION
}

\author{
Hans F. Jepsen
}

The intrusive rocks of the region around Midsommers $\phi\left(\mathrm{N} 82^{\circ} 15^{\prime}\right.$, $\left.34^{\circ}-37^{\circ} \mathrm{W}\right)$ and north of Inuiteq $\mathrm{S} \phi\left(82^{\circ} \mathrm{N}, 36^{\circ} \mathrm{W}\right)$ were studied by the writer as a member of the 4th Danish Peary Land expedition led by Eigil Knuth.

The intrusions lie in undeformed Precambrian, Eocambrian and Cambrian sediments. A simplified stratigraphic column is shown in fig. 2 .

The intrusive rocks can be subdivided into three groups: discordant sills, a flow breccia and dykes

The discordant sills and the contemporaneous flow breccia are confined to the Precambrian and lower members of the Eocambrian succession. Although definite proof is lacking, these are thought to have been intruded before the deposition of the Eocambrian cherty dolomite shown in fig. 2 . The dykes cut the complete sedimentary sequence in the area and the earlier intrusive rocks. They are clearly younger than the lower Cambrian sediments.

All the intrusions are younger than the tillites defining the base of the Eocambrian.

The discordant sills are irregular bodies (see the representation in figure 2) consisting of a central discordant stock which gives out more or less concordant sills into the surrounding flat-lying, sediments. The intrusion of the central mass does not appear to have disturbed the attitude of the surrounding sediments. The flat-lying sills vary between $0.5 \mathrm{~m}$ and $50 \mathrm{~m}$ in thickness. Large sills are commonly surrounded by swarms of smaller sills. The sills frequently show multiple intrusion. The earliest members which form the major rock type in each body are doleritic in composition. They are followed by irregular thin leucocratic veins up to $10 \mathrm{~cm}$ thick which show no obvious chilling against the basic rocks. The final phase of intrusion consists of dark fine-grained irregular veins up to $50 \mathrm{~cm}$ wide found throughout the main bodies.

The discordant sills contain many unaltered blocks of quartzite, some of which reach $30 \times 200 \mathrm{~m}$ in size. A single block of small-folded (granitic) gneiss measuring approximately $30 \times 100 \mathrm{~m}$ has been found in one of the sills. This is the only occurrence of basement rocks seen in the area apart from boulders in the tillites. 


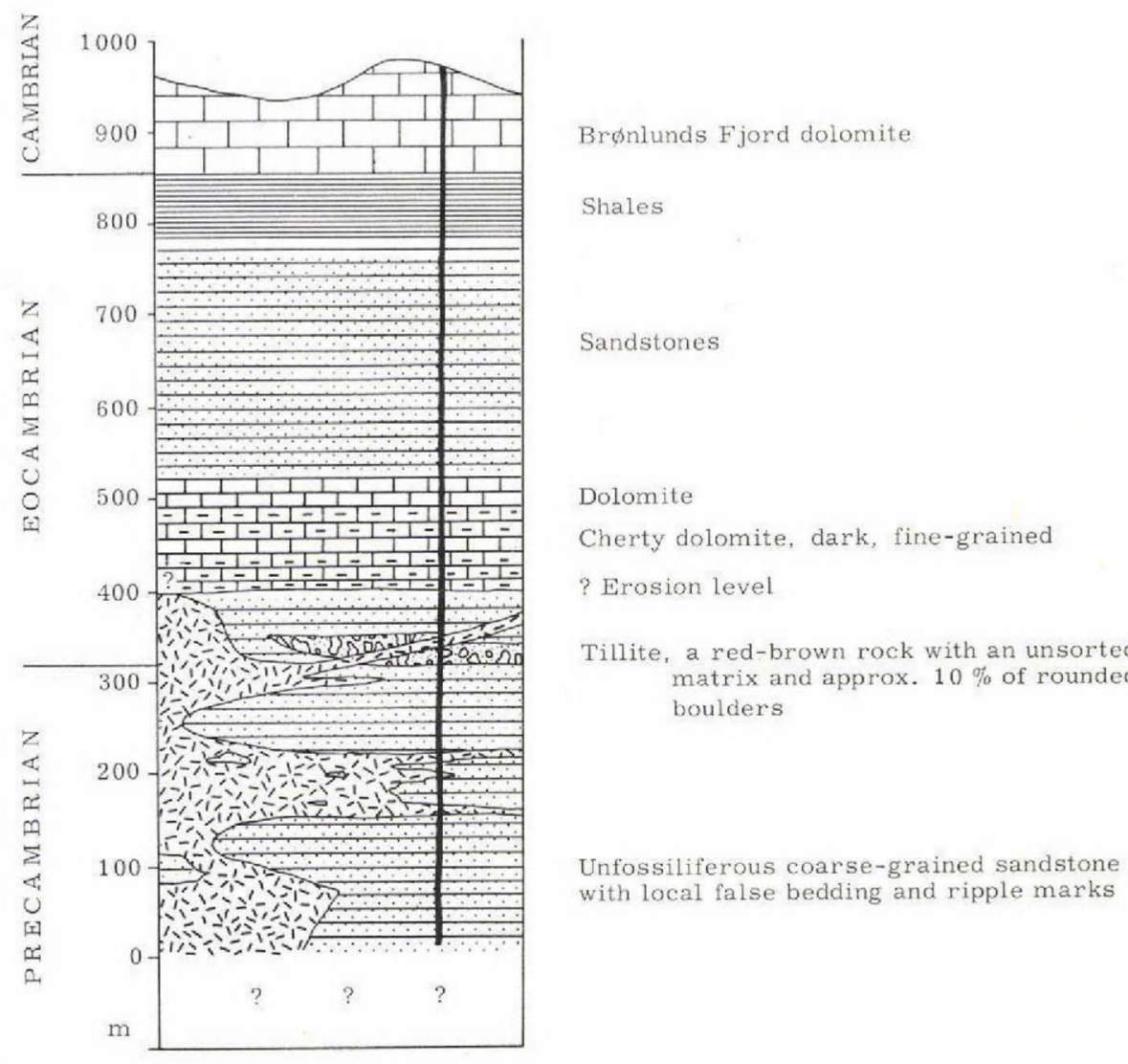

Fig. 2. Schematic stratigraphical column after Troelsen $(1949,1950)$, Berthelsen and Noe-Nygaard (1965), and modified by the author.

A single example of a flow breccia has been found in the area. This resembles the body described by Ellitsgaard-Rasmussen (1951) from Independence Fjord approximately $30 \mathrm{~km}$ to the south-east. The flow breccia is a flat-lying body approximately $20 \mathrm{~m}$ thick consisting of a fine-grained reddish matrix containing 1-2 cm xenoliths of quartzite with no preferred orientation. The flow breccia sends a $20 \mathrm{~cm}$ apophysis into an underlying sill. It is cut by an apophysis from a sill lyıng further up in the succession.

The five dykes which form the youngest intrusive rocks of the area are probably doleritic in composition. They are approximately vertical and have strikes of $150^{\circ}$. They vary in width from 10 to $50 \mathrm{~m}$ and can be followed up to $25 \mathrm{~km}$ in the field and on aerial photographs. The dykes consist of a 
greyish-brown medium-grained rock with small vesicles locally containing calcite and hæmatite. In one locality a dyke is cut by fine-grained leucocratic veins.

\section{References}

Berthelsen, A. and Noe-Nygaard, A (1965) The Precambrian of Greenland. In Rankama, K. (edit.) The Precambrian, Vol. 2, 113-262. London and New York: Interscience Publ.

Ellitsgaard-Rasmussen, K. (1951) Preliminary report on the geological field work carried out by the Danish Peary Land expedition in the year 1949-50. Medd. dansk geol. Foren., Bd. 11, [for 1950], 589-595.

Troelsen, J.C. (1949) Contributions to the geology of the area round Jørgen Brønlunds Fjord, Peary Land, North Greenland. Medd. Grфnland, Bd. 149, Nr.2.

-- (1950) Geology. In Winther, P. C. et al. A preliminary account of the Danish Pearyland expedition, 1948-9. Arctic, Vol. 3, 6-8. 